\title{
Calling Leaders to Account: A Dialogue with Jeremiah 5:1-9
}

\author{
WILHELM J. WESSELS (UNISA)
}

\begin{abstract}
Reading an ancient biblical text asking modern day questions is a challenging endeavour. In this article I attempt to engage Jer 5:1-9 in terms of leadership accountability. An analysis of this passage reveals that the prophet distinguishes between insignificant people and big people, probably referring to the peasants and the leaders in the Judean society. Jeremiah made it clear that he expected more of the leaders in terms of doing what is right; trust and truth. The leaders have failed in this regard and are therefore held accountable for the ethical demise of the Judean society. Because of their disloyalty to Yahweh and the covenant, the prophet announces punishment. In the light of what emanated from this passage an attempt was made to engage the Jeremiah text from the perspective of modern day readers with an interest in leader accountability and ethics.
\end{abstract}

KEYWORDS: Dialogue, accountability, forgiveness, ethics, worldview and leaders.

\section{A INTRODUCTION}

When reading Jer 5 it becomes clear that the prophet Jeremiah was concerned about the Judean society who in his view acted unfaithful and disloyal to Yahweh. A reading of 5:1-9 reveals that ethically the people failed Yahweh, but even more serious were the fact that the leaders acted clueless and rebellious towards Yahweh. The leaders showed a lack of accountability towards the people and most importantly towards Yahweh.

For any society to function properly, people need to be accountable to each other. Accountability serves as the checks and balances for an orderly society. But if it is required of ordinary citizens to be accountable to each other, the more so it is expected of its leaders. ${ }^{1}$ Needless to say, in most societies accountability is one of the most neglected aspects. To safeguard accountability and to regulate accountability, societies have created legal systems to preserve this ideal. In this way formal structures are set in place informed by wellargued and carefully worded laws and regulations. There is however another

* Article submitted: 13 July 2015; article accepted: 7 October 2015. To cite: Wilhelm W. Wessels, “,” Old Testament Essays (New Series) 28 no. 3 (2015): 874-893. DOI: http://dx.doi.org/10.17159/2312-3621/2015/v28n3a17

1 Lee G. Bolman and Terrence E. Deal, "The Leader as Politician: Navigating the Political Terrain," in Business Leadership: A Jossey-Bass Reader (ed. Joan V. Gallos; San Francisco: Jossey-Bass, 2008), 345. 
key role player in society that has an interest in maintaining justice, fairness and accountability, and that is the religious component. Most religions have a clear set of stipulations emanating from an ethical concern based on an awareness of a higher power that is believed to demand certain basic requirements for sound relationships both with the divine power itself and the people in relationship with this power. This is not different when it comes to the society in Judah where the relationship with Yahweh was formalised by a covenant agreement and the stipulations in the Torah to safeguard this relationship.

In this article therefore, I wish to address the issue of accountability by dialoguing with Jer 5:1-9. In v. 5 the prophet is saying he will go to the leaders (the great ones) in Jerusalem to find people who "know the way of the LORD, the requirements of their God." He concludes by saying "But with one accord they too had broken off the yoke and torn off the bonds" (Jer 5:5, NIV). This passage is situated in a particular literary context in the book of Jeremiah, but also displays relatedness to a particular period in the history of the people of Judah. The concern of this article is with the world the text presents and how we can interact with this text addressing the issue of leader accountability. ${ }^{2}$ The aim is to provide an overview of the history in the years before the commencement of the Babylonian exile to which there is general consensus amongst scholars, then to analyse Jer 5:1-9 before relating the results to a dialogue on leader accountability. What is of particular interest for the discussion is that the text in Jer 5:1-9 can be related to a time of crisis and radical change in the history of Judah. The crisis however does not only apply to the political history of Judah, but seems to be two-fold in the sense that it also concerns a crisis of leadership.

By way of introduction I want to mention three approaches of concern in this article in an endeavour to engage an ancient text in dialogue with modern day issues. The interest in this article is to relate Jer 5:1-9 to issues of leadership in modern day contexts. The text of choice will be approached with three different concerns in mind to facilitate a responsible dialogue between different worldviews. ${ }^{3}$ The various approaches are "the world behind the text, the world

2 R. Walter L. Moberly, Old Testament Theology: Reading the Hebrew Bible as Christian Scripture (Grand Rapids: Baker Academic, 2013), 17-18, 286-287.

3 Methodology is an important, but also a contentious issue. There are numerous methodological approaches in circulation. See for example the volume on methodology by Joel M. LeMon and Kent H. Richards, eds., Method Matters: Essays on the Interpretation of the Hebrew Bible in Honor of David L. Petersen (Atlanta: Society of Biblical Literature, 2009). The type of question to be asked of the text of the OT however should serve as a guideline in the choice of method. The debate is still unresolved whether meaning of a text lies in the author's intention or in the response of the reader. See in this regard J. Scott Duvall and J. Daniel Hays, Grasping God's Word: A Hands-on Approach to Reading, Interpreting, and Applying the Bible (Grand Rapids: Zondervan, 2005), 175-176; Eryl W. Davies, Biblical Criticism: A Guide to 
within the text and also the world in front of the text." At first the discussion will concern the first two approaches, but I also want to dialogue with Jer 5:1-9 in terms of leader accountability in modern day context which concerns the third approach mentioned. To do this the focus will shift to the world in front of the text, the world we as readers are acquainted with. The following quotation is relevant:

The world in front of the text focuses on the reader and the dynamics of the reading process. The reader's presuppositions form an essential part of the reader's world and are just as constitutive of meaning as the presuppositions of the author. ${ }^{5}$

The focus therefore shifts to the interest of the readers and the questions the reader pose to the text. In the dialogue between text and reader an awareness of role-player's ideologies is essential and should be critically reflected on. ${ }^{6}$ The interest of this article is therefore in what we as readers can relate to in the Jeremiah text in terms of leader accountability.

\section{B ANALYSIS OF JEREMIAH 5:1-9}

\section{$1 \quad$ Literary context}

Jeremiah 2:1-6:30 form a unit containing a preface to a cycle of poems (2:1-3), a collection of material on false cults (2:4-4:4) and a cycle of poems on "the foe from the north" and other motifs (4:5-6:26). ${ }^{7}$ The section of interest for this article, Jer 5:1-9, form part of this collection of oracles. Jeremiah 2:1-6:30 was probably collated by the Jeremiah tradition. In collating the collection the collectors and editors of the Jeremiah material may have had a threefold intention: to explain the course of history; to justify why developments had taken that particular turn; and finally to re-emphasise the importance of the covenant and its obligations on the society.

Scholars in general agree that the cycle of poems in Jer 4:5-6:26 anticipates the imminent judgement of Judah by Yahweh. ${ }^{8}$ He will use an enemy

the Perplexed (London: Bloomsbury, 2013), 11-35. I made a choice for a more integrated method that could facilitate a dialogue between questions posed to the text of the OT relevant to a modern day society, but at the same time do justice to the OT as an ancient text.

4 W. Randolph Tate, Biblical Interpretation: An Integrated Approach (Grand Rapids: Baker Academic, 2011), 277-324.

5 Tate, Biblical Interpretation, 298.

6 David J. A. Clines, Interested Parties: The Ideology of Writers and Readers of the Hebrew Bible (Sheffield: Sheffield Phoenix Press, 2009), 23-25; Tate, Biblical Interpretation, 325-326.

7 Robert P. Carroll, Jeremiah (London: SCM, 1986), 86.

8 Carroll, Jeremiah, 160; William McKane, Jeremiah (Edinburgh: T \& T Clark, 1986), 90. 
from the north, which is a reference to the Babylonians. O'Connor calls this collection of poems "War poems.",

\section{$2 \quad$ Historical Context}

The period in Judah's history when Jeremiah acted as prophet can be labelled a time of crisis due to international political circumstances which affected the internal politics and religious life in Judah. On the international scene Assyria, Egypt and eventually Babylonia dominated the scene. In Judah some people had pro-Egyptian sentiments, whilst others were more pro-Babylonian inclined. All of this played a vital role in the society of Judah and in particular the inhabitants of Jerusalem. A brief overview will suffice to illustrate the crises during this period in Judah's history. The people had to deal with the death of king Josiah in 609 B.C.E. by Farao Necho II of Egypt, the deportation of king Jehoahaz (Shallum) after three months to Egypt, the abuse of power by king Jehoiakim (609-598 B.C.E.), accusations of idolatry, moral depravity and the besieging of Jerusalem by the Babylonian forces during his reign. This is followed by the deportation of king Jehoiachin in 597 B.C.E. and finally the invasion and destruction of Jerusalem and the temple and the deportation of king Zedekiah in 586/7 B.C.E. to Babylon. ${ }^{10}$ This concise overview clearly depicts turbulent times for the people of Judah.

\section{Jeremiah as Religious Leader}

It is difficult to distinguish between the historical Jeremiah and the literary figure Jeremiah as he is presented in the book of Jeremiah. We know from the book of Jeremiah that he is of priestly descent and most probably a priest himself (cf. Jer 1:1), born in Anatoth, the Levites' priestly city. Jeremiah was from the Mushite Levites and his call narrative reveals rituals associated with the Levitical cult. ${ }^{11}$ Jeremiah's way of thinking and content of his messages were most probably influenced by the fact that Anatoth was located on the border of Northern Kingdom and that the city had a Levite priestly history. ${ }^{12}$ It offers a

9 Kathleen M. O'Connor, "Reclaiming Jeremiah's Violence," in Aesthetics of Violence in the Prophets (ed. Chris Franke and Julia M. O'Brien; New York: T\&T Clark, 2010), 41.

10 Cf. Terence E. Fretheim, Jeremiah (Macon, Ga.: Smith \& Helwys, 2002), 3; Louis Stulman, Jeremiah (Nashville: Abingdon Press, 2005), 2-4.

11 Mark Leuchter, "Cult of Personality: The Eclipse of Pre-Exilic Judahite Cult Structures in the Book of Jeremiah," in Constructs of Prophecy in the Former \& Latter Prophets \& Other Texts (ed. Lester L. Grabbe and Martti Nissinen; Atlanta: Society of Biblical Literature, 2011), 96-97.

12 Joseph Blenkinsopp, Sage, Priest, Prophet: Religious and Intellectual Leadership in Ancient Israel (Louisville, Ky.: Westminster John Knox, 1995), 66-114; see also Lena-Sofia Tiemeyer, "The Priests and the Temple Cult in the Book of Jeremiah," in Prophecy in the Book of Jeremiah (ed. Hans M. Barstad and Reinhard G. Kratz; Berlin: Walter de Gruyter, 2009), 233-264. 
possible explanation for the presence of Northern traditions in Jeremiah's proclamation. ${ }^{13}$

Shaphan was a person who played a significant role in Jeremiah's life. He was secretary in King Josiah's administration and the temple was also under his jurisdiction. Shaphan received the Book of the Law that was discovered in 621 B.C.E. from Hilkiah and read it to the king (2 Kgs 22:3-10). It was most probably Shaphan who introduced Jeremiah to the Book of the Law which strongly influenced Jeremiah's views and convictions. Due to his acquaintance with Shaphan and interest in Book of the Law, Jeremiah formed relationships with both the temple and the royal household. ${ }^{14}$ Shaphan was a key figure in King Josiah's reform initiative and he and his sons were very loyal followers of Josiah. $^{15}$ The family of Shaphan affected Jeremiah's existence in very significant ways. ${ }^{16}$ Jeremiah enjoyed support from the Shaphan family and due to this relationship had good knowledge of what Josiah's reform program entailed. This could perhaps serve as explanation for the Deuteronomistic-ethical principles present in Jeremiah's proclamation. ${ }^{17}$

The assumption can be made that Jeremiah's worldview was informed or shaped by covenant theology in the tradition of Moses. ${ }^{18}$ Jeremiah's theology therefore reveals influence of Northern kingdom traditions. The prophet reveals a strong understanding of what ethical behaviour entails. His choice of words however also reveals that he was influenced by practical wisdom based on observations and experiences from every day relationships. ${ }^{19}$ He emphasises the need for fairness and truthfulness (faithfulness) in relationships in order to establish and maintain an orderly society (cf. Jer 22:15-17). Jeremiah is presented as a strong proponent of the fact that Yahweh alone should be worshiped

13 Rainer Albertz, "Jer 2-6 und die Frühzeitverkündigung Jeremias," ZAW 94 (1982): 43-44.

14 Tiemeyer, "The Priests," 234 argues that in the persona of Jeremiah the offices of priest and prophet are combined. Jeremiah was familiar with the temple surroundings and as a prophet the king and the royal household were always his concern.

15 Norbert Lohfink, "Die Gattung der 'historischen Kurzgeschichte' in den letzen Jahren von Juda und in der Zeit des babylonischen Exils," ZAW 90 (1978): 336.

16 David J. Reimer, "Redeeming Politics in Jeremiah," in Prophecy in the Book of Jeremiah (ed. Hans M. Barstad and Reinhard G. Kratz; Berlin: Walter de Gruyter, 2009), 133-135.

17 Cf. Leuchter, "Cult of Personality," 97-98; Walter Brueggemann, Like Fire in the Bones: Listening for the Prophetic Word in Jeremiah (Minneapolis: Fortress, 2006), 21-22.

18 Jack R. Lundbom, Jeremiah Closer Up: The Prophet and the Book (Sheffield: Sheffield Phoenix Press, 2010), 35-37.

19 Leslie C. Allen, Jeremiah (Louisville: Westminster John Knox, 2008), 73. 
Wessels, "Calling Leaders to Account," OTE 28/3 (2015): 874-893

and he vehemently opposed any form of syncretistic worship. ${ }^{20}$ The covenant relationship with Yahweh is central in Jeremiah's worldview ${ }^{21}$ and that determined his expectations and demands from people.

\section{$4 \quad$ Exposition of Jeremiah 5:1-9}

In an article I have submitted for publication, I have analysed the text of Jer 5:1-6 in detail. ${ }^{22}$ The larger section 5:1-9 can be subdivided in 1-6 and 7-9. For the discussion of this paper 5:1-9 will be the focus of discussion. Jeremiah 5:16 can further be subdivided into vv. 1-2 (Yahweh speaking), 3-5 (thoughts of the prophet) and v. 6 as the verdict.

In 5:1 implementing four imperatives, Yahweh commands an unidentified group of people to feverishly search the streets and the squares in Jerusalem to look for a person who acts justly (mišpa ț $)^{23}$ and who seeks to be trustworthy or faithful ('êmūnōh). This last mentioned concept expresses the quality of trust that develops from a close relationship. ${ }^{24}$ In this context it refers to faithfulness to Yahweh as the covenant God in response to his loving-kindness to his people. ${ }^{25}$ If such a person is to be found, then Yahweh will forgive the people of Jerusalem. Verse 2 continues the woeful situation by declaring that the people uses Yahweh's name to take an oath, but they do that falsely (̌̌êqêr). This concept can also be translated as "deception" or "lies" and is frequently used in the book of Jeremiah. ${ }^{26}$ Instead of just actions and honesty, there are dishonesty and lies. From the first two verses of the chapter it is already clear that Jeremiah was concerned about the moral state of the society in Judah. There were no people who did what was right, trustworthy and truthful.

20 Morton Smith, Palestinian Parties and Politics that shaped the Old Testament (New York: Columbia University Press, 1971), 24, 45.

21 Cf. Christl Maier, Jeremia als Lehrer der Tora (Göttingen: Vandenhoeck \& Ruprecht, 2002), 370-372.

22 Wilhelm J. Wessels, "Leaders and Times of Crisis: Jeremiah 5:1-6 A Case in Point," JSem (forthcoming).

21 Most of these references express what Yahweh expects of leaders such as the kings of Judah and their administrations. Wilhelm Rudolph, Jeremia (3rd enhanced ed.; Tübingen: JCB Mohr, 1968), 37 regards mišpāt in this context as an ethical term in the sense of living according to the will of Yahweh.

24 John Reumann, "Faith," EDB: 453-545.

25 McKane, Jeremiah, 116.

26 See the study of Thomas W. Overholt, The Threat of Falsehood: A Study in the Theology of the Book of Jeremiah (London: SCM, 1970), 86-104; also Kathleen M. Rochester, Prophetic Ministry in Jeremiah and Ezekiel (Leuven: Peeters, 2013), 161162. The concept $\breve{s} \hat{e} q \hat{e} r$ is often used in the book of Jeremiah and appears in Jer 5:1; $7: 5 ; 9: 23 ; 22: 3 ; 22: 15 ; 23: 5$ and 33:15. 
Jeremiah 5:3 proclaims that Yahweh demands honesty ('êmūnōh). The implication is clearly that honesty is nowhere to be found with the result that Yahweh has struck them and even crushed them, but to no avail. Yet instead it is said that "they felt no anguish" and "they refused correction." To emphasise the rebellious and stubborn attitude of the people, it is said "they have made their faces harder than a rock" and "they have refused to turn back." We gather from this verse that the people not only lost their moral direction, but that they display an attitude of stubbornness and rebellion. They go so far as to refuse to turn back to Yahweh and who are their covenant partner.

The next two verses (5:4 and 5:5) are of prime importance for the argument of this paper. Whereas the prophet spoke more in general in the previous verses, in these verses he is more specific by referring to "insignificant people" (dallîm), ${ }^{27}$ on the one hand (5:4) and the "big ones" (hag dôlîm) on the other hand (5:5). ${ }^{28}$ The prophet speaks his mind by saying that what has transpired in the Judean society as expressed in the previous verses (5:1-3) is that the "less significant people/peasants" ${ }^{29}$ lack knowledge of "the way of Yahweh" and the "law or justice of Elohim." Jeremiah's first thoughts therefore were that the foolish behaviour could be because the "dallîm" were the less educated people in the society. The lack of knowledge of the way of Yahweh and of the law of Elohim most probably refer to a lack of knowledge of the will of Yahweh as expressed in the Torah and reflected in the covenant stipulations.

Jeremiah then turned his attention to the next category of people mentioned in v. 5 as the "big ones." Many of the translations interpret this reference as an indication that Jeremiah was speaking of the leaders in the Judean society. Others go even further by translating this word to mean "the rich people." What is clear from this verse is that the prophet had higher expectations of this group of people he was referring to when it is stated "surely they know the way of the Lord, the law of their God." However to the dismay of the Jeremiah, this

27 In Ruth 3:10 the "dal" is contrasted with the "rich," and therefore should be translated with "the poor." In Lev 19:15 both the nouns "dal" and "gadôl" are used and in Holladay's view should be understood as meaning the powerless and those with power respectively. See William L. Holladay, Chapters 1-25 (vol. 1 of Jeremiah: A Commentary on the Book of the Prophet Jeremiah; Philadelphia: Fortress, 1986), 178. In Amos 2:7 and Prov 10:15 and 14:41, "dal" in the context of the verses should be translated as "the poor."

28 Note that the reference to the $h^{e} g^{e}$ dôlim has a definite particle, absent in the reference to the dallîm. This is probably an indication that a more defined group of people are meant, the more educated such as the leaders and the officials. See Holladay, Jeremiah 1, 178; Berend J. Oosterhoff, Jeremia 1-10 (Cout; Kampen: Uitgeversmaatschappij J H Kok, 1990), 192.

29 According to William R. Domeris, "Jeremiah and the Poor," in Uprooting and Planting: Essays on Jeremiah for Leslie Allen (ed. John Goldingay; London: T\&T Clark, 2007), 53 this is probably a reference to the poor peasants. 
group of people did not show any more insight or acted in such a way that they display knowledge of what Yahweh expected of them. Truth of the matter is, their behaviour and attitude was not dissimilar to that of the people of whom less was expected. The people of Judah had no regard for their relationship with Yahweh, instead in rebellious fashion they "had broken the yoke and burst the bonds." 30 They were disobedient, disloyal and dismissive of any requirements demanded by the covenant relationship with Yahweh. In all essence, their actions boil down to deliberately freeing themselves from the binding the covenant has on their existence. ${ }^{31}$

In Jer 5:6 Yahweh's response to their disobedience and rebellious attitude is concluded in an expression of judgement. By using metaphors of vicious wild animals such as the wolf and the leopard, Yahweh announces that the people will be trapped in Jerusalem and anyone who dares to exit the city will fall prey to these vicious animals. In terms of the literary context of Jer 5:1-6 and the historical context reflected by the book of Jeremiah, these metaphors most probably refer to the threat caused by the Babylonian armies. ${ }^{32}$ Verse 6 concludes with a summary statement that all of this is "because their transgressions are many, their apostasies are great." The two nouns transgression (pêša ) and apostasy (mešū $b \bar{a})$ both indicate that the people acted unethically and disobedient towards Yahweh and destined for punishment.

I argued in the beginning of the article that Jer 5:1-9 forms a unit that could be subdivided into vv. 1-6 and 7-9. There is a clear relation with regard to content between these two units in ch. 5 , but it is syntactically possible to treat them as subunits. There is a change to a first person singular subject in $\mathrm{v}$. 7 alluding to Yahweh as the speaker of this unit. It is also important to note the difference in style in the sense that we find interrogatives in v. 7 and v. 9. With regard to content Jer 5:7-9 seems to be a response to the previous six verses. The impression is created that these three verses make explicit what is implicitly alluded to in 5:1-6. In vv. 7-9 Yahweh addresses Jerusalem and her inhabitants. It therefore seems to be an addition from a later period in history commentating on vv. 1-6. ${ }^{33}$

Verse 7 commences with a question of why Yahweh should forgive Jerusalem (2nd person fem. sg. suf.). This clearly brings the whole matter of forgiveness to the centre stage and links back to v. 1 . In Jer 5:1 it was pointed

30 Dalit Rom-Shiloni, “'How Can You Say, “I Am Not Defiled ...”?' (Jeremiah 2:20-25): Allusions to Priestly Legal Traditions in the Poetry of Jeremiah," JBL 133/4 (2014): 760 argues that these metaphors express rebellion by the people and the leaders.

31 Allen, Jeremiah, 73.

32 A. R. Pete Diamond, "Jeremiah," in Eerdmans Commentary on the Bible (ed. James D. Dunn and John W. Rogerson; Grand Rapids: Eerdmans, 2003), 555.

33 Carroll, Jeremiah, 178-179. 
out that Yahweh was willing to forgive Jerusalem with the provisio that a single person could be found who acts justly and trustfully. As the passage unfolded it has become clear that Jerusalem and its inhabitants did not meet Yahweh's requirements. From the question posed in v. 7 it seems that there were people who took issue with the matter that Yahweh acted unforgivingly. In response to the unhappiness of Yahweh acting unforgivingly, the question is posed why should Yahweh forgive Jerusalem and their inhabitants? Whereas the previous section alluded to unjust actions such as unfaithfulness, deceit, stubbornness, rebellion and lack of knowledge of Yahweh, summarised as many transgressions and great apostasies (cf. 5:6), vv. 7b-8 give content to all of these concepts. Verse 7 states that their attitudes and actions boil down to rejection of Yahweh as their covenant partner. To communicate it even more explicitly it is said that they have forsaken ${ }^{34}$ Yahweh and worshipped gods who were not real gods. Their disloyalty to Yahweh is effectively depicted by a metaphor referring to the people of Judah as adulterers. ${ }^{35}$ Their adultery is described as "they have spent time at houses of prostitutes." ${ }^{36}$ It is possible that this is a reference to some of the cultic practices of prostitution associated with pagan shrines. $^{37}$

Verse 8 expands even more on the adulterous behaviour of the people of Judah by again using a metaphor. The people of Judah are compared to wellfed and lusty stallions. Building further on the metaphor of lusty stallions, the unethical behaviour of a man of "neighing" for his neighbours wife is portrayed. Allen ${ }^{38}$ has pointed out that in v. 7 religious infidelity is depicted in sexual terms whilst in v. 8 "by association of ideas religious metaphor gives way

34 The expression "they have forsaken me" is used in $1 \mathrm{Kgs} 11: 33 ; 2 \mathrm{Kgs} 22: 17 ; 2$ Chr 34:25; Jer 1:16 and 5:7, indicating the worship of foreign gods or idols.

35 Jeremiah uses the verb "adultery" or the noun "adulterers" in the double meaning of unfaithfulness to Yahweh by worshipping foreign gods (cf. Jer 3:9; 9:2 pi 'el; 23:10), but also to refer to unethical adulterous deeds with another person's wife (cf. Jer $7: 9 ; 23: 14 ; 29: 23)$. In 5:7 both these transgressions are combined in the rituals of prostitution in the cultic worship of idols.

36 There is a textual problem with the verb gdd (hitpol' $e l$ ) in the MT which should be translated as "they have cut themselves." The LXX has a different translation "they lodged" at the houses of prostitutes. After weighing all the options, Jan de Waard, A Handbook on Jeremiah (Winona Lake: Eisenbrauns, 2003), 17 emphasises the necessity to change the text in favour of the LXX that probably had a Vorlage of the Hebrew Text and suggests the possible translations of "and frequented brothels" or "and spent their time with prostitutes."

37 Oosterhoff, Jeremia 1-10, 194-195 indicates that the Canaanite religion was a fertility cult with fertility rituals. These rituals were practiced with prostitutes at the shrines in honour of the fertility goddess Astarte. Werner H. Schmidt, Das Buch Jeremia: Kapitel 1-20 (Göttingen: Vandenhoeck \& Ruprecht, 2008), 144 refers to Hos 4:12-14 as a description of these adulterous practices.

38 Allen, Jeremiah, 73. 
to literal sexual immorality" in that a man's lusting for his neighbour's wife is depicted by a metaphor of lusty stallions. ${ }^{39}$

Just as v. 6 concluded that Yahweh will punish ${ }^{40}$ his people, so does v. 9 for the sub-section 5:7-9. The text unit started with a question in v. 7 with Yahweh asking for what reason he should forgive the people as there seems to be no reason to do so. Verse 9 concludes the section again employing the same rhetorical strategy by asking two questions. The questions are formulated in such a way that the people of Judah can come to no other logical conclusion in the light of what preceded in vv. 7 and 8 that they deserve punishment for their disloyalty to Yahweh and their grave unethical behaviour. There is no other conclusion to be drawn than that Yahweh should bring retribution on a nation who has behaved thus dreadfully. ${ }^{41}$ It is interesting to note that this verse, using the same wording, is repeated in Jer 5:29 and 9:8.

If there is any validity in my proposed reading of Jer 5:7-9 as a later interpretation of 5:1-6, then a situation should be envisaged of people struggling with the fact that Yahweh did not forgive his people. It might be a situation in the exilic or even in the post-exilic period when people were struggling with questions about Yahweh. The theodicy questions concerned the matters of Yahweh's forgiveness and whether his judgement of his people was justified. The view of the compiler or editors of the Jeremiah oracles is that Yahweh's punishment was justified.

\section{RELATING JEREMIAH 5:1-9 TO LEADERSHIP MATTERS}

The question to be answered at this stage is how does all of this relate to the matter of leadership? We have learnt from 5:1-6 that the society in Judah and Jerusalem in general terms showed an absence of people acting justly and faithfully, and that even when they used Yahweh's name it was done deceitfully. The people of Judah stubbornly refused to turn back to Yahweh and be faithful covenant partners. They reacted indifferently and rebellious towards Yahweh and had no scruples in breaking free from the stipulations of the covenant. Jeremiah concluded that the actions and the attitudes of the people of Judah could be described as a lack of knowledge of the way of Yahweh, which is qualified as the law of Elohim. What is of importance for the argument presented in this article, is that a distinction is made between ordinary people (peasants) and those in leadership positions. More was expected of the leaders and the educated people in the society in terms of what it implied to be in good standing

39 Carroll, Jeremiah, 179-180 cautions that the imagery in vv. 7 and 8 are not all that clear whether sacred or secular prostitution are meant or even whether the metaphors are used to illustrate infidelity towards Yahweh.

40 The verb pqd "to visit of attend to" (qal 1st person sg.) is often used to indicate punishment by Yahweh (cf. Isa 10:12; Jer 5:29; 9:8; 25:12; $27: 8$ and Amos 3:2).

41 Allen, Jeremiah, 74. 
with Yahweh. It is therefore logical to conclude that the leaders in the society not only failed the people of Judah, but in particular Yahweh. If we add the later perspective provided in 5:7-9, then it seems that the leaders and the upper echelons of the society were to be blamed for the infidelity of the people towards Yahweh and the moral depravity of the society. Yahweh is therefore not to be blamed for not forgiving or unfairness towards his people, there is justification for the punishment and retribution on the nation. Even if the ordinary people in Jerusalem and the Judean society could be blamed for Yahweh punishing them, the more so the leadership. ${ }^{42}$

From what we have learnt how the book of Jeremiah portrays the prophet, it is clear that he viewed everything from the covenant relationship with Yahweh and the ethical demands that flow from this relationship. ${ }^{43}$ In his view the people had an ethical obligation towards Yahweh that should be reflected in their faithfulness in worshipping Yahweh alone and in their truthful and just actions. There are many examples in the book of Jeremiah that support the view that the leadership in particular was expected to be the custodians of justice, fairness and truthfulness. In Jeremiah's view leaders such as the kings and their officials failed dismally in this regard. Jeremiah regarded the leadership in Judah as failed leadership who should be blamed for the ethical demise of the people and the resultant punishment by Yahweh at the hands of the Babylonians. Jeremiah holds the leaders in particular accountable for the moral decay and the rebellious attitude displayed by the Judean society which resulted in the break of the relationship with the covenant God. ${ }^{44}$

\section{$1 \quad$ A Next Generation of Readers}

It is nowadays commonly accepted that followers of Jeremiah collected and preserved his oracles and were responsible for the writing down and organisation of the book now called the book of Jeremiah. These tradents not only collected the Jeremiah oracles but also responded to the oracles in terms of questions that were prevalent in their own society. As argued it is possible that Jer 5:7-9 is an example of how people in the exilic or even the post-exilic period battled with the theodicy question of Yahweh's forgiveness and justification for

42 There are many instances in the book of Jeremiah where the leaders are blamed for the misfortunes of the people of Judah. Examples to mention a few are Jer 2:26 where kings, priests and prophets are blamed for being unfaithful towards Yahweh and 6:13 referring to priests and the prophets guilty of greed for false gain. Lager sections dealing with leader issues include Jer 21:1-23:8 (the kings) and 23:9-40 (some prophets).

43 Cf. Brueggemann, Like Fire, 143-145; Christl Maier, Jeremia als Lehrer, 370372.

44 Cf. Rowan Williams, "Making Moral Decisions," in The Cambridge Companion to Christian Ethics (ed. Robin Hill; Cambridge: Cambridge University Press, 2001), 6-7. 
punishment. What is important for the argument of this article is that some people at a later stage in the history of Judah interpreted Jer 5:1-6 and made the content more explicit as to why the people of Judah deserved punishment, that Yahweh was justified in not forgiving them. This interpretation made it even clearer that the leaders have failed the society in terms of ethical matters. The leaders should therefore be called to account for failing to safeguard the ethical fibre of society. From this perspective the leaders should be called to task for failing to lead the people in worship of Yahweh alone and no other gods. They failed in upholding the ethical demands of the covenant relationship with Yahweh which resulted in the moral demise of the people as is explicitly demonstrated by the adulterous practices of the people of Judah. They as the educated leaders demonstrated a sorry lack of knowledge of "the way of Yahweh" and "the law of Elohim." If this re-reading of Jer 5:1-6 is convincing then it displays an appropriation of a text in a later context.

\section{Modern Day Readers}

When we as modern day readers enter into dialogue with Jer 5:1-9 in terms of leadership issues, we do so as yet another party in the long line of interpreters of this ancient text from our particular context and society's concerns. It should be realised that we do not come to the biblical text as innocent readers, but as people with interests and struggles that emanate from our societies. If we then approach the text with a concern for leadership issues, we do so in terms of the leadership issues in our societies. It is also important to acknowledge that how we regard the text in terms of its value and relevance will determine how serious we will take the text as a dialogue partner. Only if we take the text seriously will it be able to inform our views and enrich the dialogue. The issue of the authority of the biblical text is complex as is illustrated in a discussion offered by Brueggemann. ${ }^{45}$ What I in particular appreciate is his emphasis on the inherent power of the text to convince readers to take it seriously. He says "authority is recognized (not given) by a public judgment that this text bears authority in its powerful offer of truth, which has been recognized over time as having an inescapable claim upon us." 46

The text of the OT is a reflection of how people related to Yahweh and their struggles to relate their decisions and actions in terms of this relationship. ${ }^{47}$ The OT is a religious text and reflects views on issues from a religious perspective. The text of the OT concerns relational issues that are based on ethical principles. As a dialogue partner on leadership issues then, the OT texts will

45 Walter Bruegggemann, The Book that Breathes New Life (Minneapolis: Fortress, 2005), 3-19.

46 Brueggemann, The Book, 10.

47 Bruce C. Birch et al., A Theological Introduction to the Old Testament (Nashville: Abingdon Press, 1999), 17-19. 
concern ethical issues of leadership. Jeremiah 5:1-9 is a good example of a reflection on ethical issues in terms of leadership.

Dealing with ancient texts and relating them to our contemporary societies certainly has its challenges. We cannot relate ancient texts directly to our societies as they are operating from diverse worldviews. To quote Carroll "The social world of ancient Israel differs considerably from that of advanced industrial societies, and reading its writings from a modern ideological perspective can be very misleading. $" 48$ In spite of the reality of the remoteness and strangeness between the world or worlds of the OT and our worlds, constructive dialogue seems possible. To quote Houston in this regard:

Each historical period, and every text, has its horizon and lies within a world. The true understanding of a work of the past, as Gadamer sees it, involves not only "transposing ourselves into the historical horizon" to listen to it in its proper context, but allowing that horizon to merge or fuse with the horizon of our own world by making adjustments in our understanding so that we find ourselves with a new, broader horizon within which to understand ourselves and our world. ${ }^{49}$

The world from which the text of Jer 5:1-9 emerges is totally different from the world of the exegete and readers of this passage today. ${ }^{50}$ The view promoted by the prophets of the OT is that of a theocratic leadership, meaning that God is king and that the earthly king operates as a vassal of Yahweh. When the monarchy gained momentum in Israel, matters became more complicated and the theocratic ideal more difficult to maintain and to protect. ${ }^{51}$ The Judean society was supposed to be a theocratic society with God as the real power and other leaders such as the king representing his power on earth. In the case of Judah the relationship with Yahweh was regarded as a covenant relationship with Yahweh as the senior partner in the relationship demanding of the people to respond to his kindness and loyalty by obeying him. His will is expressed in the Torah and the covenant stipulations, which I have argued is founded on ethical principles. In modern societies the ideal is that of a democratic society where the power is supposed to be with the people and the leaders they elect to uphold the principles and values the people cherish. In this regard the leaders in society are supposed to represent the will of the people. It is also a fact that most societies today are secular in nature and that the expec-

48 Carroll, Jeremiah, 180.

49 Walter J. Houston, Contending for Justice: Ideologies and Theologies of Social Justice in the Old Testament (London: T\&T Clark, 2006), 6.

50 Although Houston, Contending, 5-6 raises the hermeneutical problem of the differences between our worlds and the world of the Bible, dialogue between Jer 5:1-9 and our worlds can in his words "broaden our horizons" of understanding.

51 Cf. Ebenezer O. O. Adeogun, "The Kingdom of God and Old Testament Theocracy," OJT 12 (2007): 69-70. 
tation cannot be that the leaders would necessarily uphold theocratic principles. The implication of this change in worldview and governance structures is that church and state is separate and that those who view society from a religious perspective should act as prophetic voices to society in general and to leaders in government and societal structures in particular. In relating OT texts to public contexts the following quotations seems relevant: "The theological significance of the OT rests in the conviction that these texts constitute a witness in behalf of the God of Israel that can make a difference in the public issues and crises of our time." 52 The point this article wishes to make is that dialogue between prophetic texts from the OT and modern public contexts can constructively contribute to address accountability of leaders in public contexts. Religious communities today form part of a long interpretive tradition and when confronted with ethical issues such as those that emanated from Jer 5:1-9, they need to interpret these issues within their religious communities which again form part of the bigger community of their social world. This implies that these ethical concepts need to be defined in relation to God and their faith communities, but also in relation to the secular world informed by science, economic knowledge, social structures and cultural realities etcetera. What it boils down to is to faithfully and respectfully dialogue with OT texts (also NT text), but in the end taking responsibility for re-defining and appropriating these ethical issues within the context of modern day enlightened society. ${ }^{53}$

When looking at societies in the world today, it is clear that there is a dire need for voices that promote ethical principles to improve our societies. Each and every society relies on sound relationships; be it between members of the various communities or between people and societal structures. For that to happen there need to be sound ethical principles that regulate these relationships. ${ }^{54}$ Societies usually address these demands by promulgating laws, but that immediately implies that laws should be enforced. A more ideal situation would be when people in society operate naturally grounded in sound ethical principles and good values. In this regard religious contexts promoting sound religious principles can play a crucial role in installing such value systems. ${ }^{55}$ In

52 Birch et al., Theological Introduction, 27.

53 An informative essay in this regards is written by Gareth Jones, "The Authority of Scripture and Christian Ethics," in The Cambridge Companion to Christian Ethics (ed. Robin Hill; Cambridge: Cambridge University Press, 2001), 16-28.

54 Bolman and Deal, The Leader as Politician, 345-346 mention several diagnostic question political leaders should ask when making decisions what is ethical. Cf. also Duncan B. Forrester, "Social Justice and Welfare," in The Cambridge Companion to Christian Ethics (ed. Robin Hill; Cambridge: Cambridge University Press, 2001), 195-198, 206. He in particular refers to God's justice as displayed in the covenant relationship with his people and how it can serve as a guiding principle in modern day human relationships.

55 At times we make decisions we consider to be right without much self-analyses. We become who we are and make decisions accordingly because of relations such as 
terms of what have emerged from the Jeremiah text concerning leadership, a prophetic appeal can be made to leadership to be accountable to Yahweh, but also to the people of the society to be accountable. It is not far-fetched to expect leaders to uphold justice and to act in such a way that people regard them as trustworthy and truthful. ${ }^{56}$ Even if a society is secular in nature, there is still a need for leaders to be accountable to the people and to uphold the principles of justice, fairness and trustworthiness. ${ }^{57}$ There is a strong emphasis nowadays in literature for business and politics to uphold the aforementioned principles. ${ }^{58}$ In this regard then we can clearly relate what have been highlighted in the exposition of Jer 5:1-9 to leaders and leadership structures in our societies.

\section{Critical Engagement of Jeremiah}

As readers however we also need to engage some aspects that have surfaced from Jer 5:1-9 critically. ${ }^{59}$ The idea was promoted that we should take Jeremiah's ethical approach and demands seriously as they seem relevant to the dialogue of what can be expected of leaders today. However, I briefly want to raise two issues of concern in the text. In dialoguing with the text one of the aspects that passed almost unnoticed is the fact that Jeremiah simply mentions the categorising of the society into class structures. He has a concern with the unethical behaviour of people and leaders as discussed before, but not with the reality that the society consists of "small people" or peasantry on the one hand and the so-called "big people," the educated and wealthy people in positions of power on the other hand. ${ }^{60}$ It is perhaps unfair to criticise the prophet in this regard since in other sections in the book he criticises the king for neglecting

culture, language and people that impact on us. We are formed by our world consisting of many influences, and exposure to biblical ethical principles definitely contributes to our shaping and decision-making. Cf. Williams, "Making Moral Decisions," 46.

56 Cf. David Batstone, "Preserving Integrity, Profitability, and Soul," in Business Leadership: A Jossey-Bass Reader (ed. Joan V. Gallos; San Francisco: Jossey-Bass, 2008), 463-485.

57 Andrew J. DuBrin, Principles of Leadership (7th ed.; Australia: SouthWestern, Cencage Learning, 2013), 144-163 dedicates a whole chapter to the moral aspect of leadership. He prioritises the following ethical behaviours needed in organisations: honesty, trust, integrity and loyalty.

58 See the insightful article by Andre L. Delbecq, "Nourishing the Soul of the Leader: Inner Growth Matters," in Business Leadership: A Jossey-Bass Reader (ed. Joan V. Gallos; San Francisco: Jossey-Bass, 2008), 487-503 where he addresses issues such as spiritual intelligence, authenticity, integrity of beliefs, respect for humans, human dignity, spiritual values, common good, justice and the needs of the poor.

59 Birch et al., Theological Introduction, 19-20.

60 Houston, Contending, 18-51 devotes a chapter to various societal structures that existed in Israel and Judah. He discusses structures such as rent capitalism, 'Ancient' class society, the tributary state and the patronage system. 
the poor and the needy. ${ }^{61}$ However as a reader of the text this aspect stood out as a concern to me perhaps because so many societies uncritically accept this class distinction as a fact of life. The divide between rich and poor is a social concern that plagues many modern day societies and need to be addressed. ${ }^{62}$ As prophetic voices in societal matters of class division, education and poverty should concern us and leaders should be sensitised and called to account with regard to these matters. The roles of prophets in addressing these issues need further investigation.

The second aspect I wish to critique is the matter of divine retribution. ${ }^{63}$ In profiling Jeremiah's outlook as he is portrayed in the book of Jeremiah, it was argued that Jeremiah departed from a covenant theology strongly promoted in the book of Deuteronomy that operated with a notion of divine retribution. ${ }^{64}$ I am not contesting the fact that Jeremiah expected the people to be loyal to Yahweh and to live in obedience to his will, but the concern is that deed and consequence are directly related. This is a very narrow way of looking at reality that easily develops into a stagnated dogmatic view of blessing for good deeds and punishment for doing something wrong. Whereas there was a more natural flow between cause and effect at first, it later developed into a rigid dogmatic doctrine of divine retribution associated with the Deuteronomy school of thought. The problem arising is that people who experienced bad or negative things or noticed others having negative experiences, concluded that that was the result or should be related to some form of wrongdoing, sin or disobedience. The impact of this way of thinking is clear in Jeremiah's proclamation of doom and judgement. In the case of Jeremiah the disobedience and stubbornness of the people were directly related to the threat of the approaching Babylonian army acting as an instrument of Yahweh's punishment. People who experienced the exile and the negative conditions of being in exile concluded that this must be punishment from Yahweh for sin, disobedience and disloyalty of worshipping gods who are no gods (5:7-9). ${ }^{65}$ The Jeremiah tradition used the same line of thinking when it comes to judging the leaders of Judah from a

61 Cf. Jer 7:3-7; 22:15-16.

62 Houston, Contending, 226-230.

63 Stephen B. Chapman, "Reading the Bible as Witness: Divine Retribution in the Old Testament," PRSt 31/2 (2004): 175-177.

64 It is very difficult to distinguish between the "real" Jeremiah and the Jeremiah of the book of Jeremiah. The Jeremiah of the book of Jeremiah seems to promote the idea that Judah's sins and transgression were responsible for the threat and eventually the Babylonian exile. This Jeremiah is therefore an exponent of divine retribution. There is however also a Jeremiah who questions Yahweh on the fact that he as someone who is dedicated to his calling is suffering. This Jeremiah is also disturbed because it seems that dishonest and wicket people thrive (Jer 12:1).

65 It is probably the same people responding in Jer 5:7-9 that formed part of the Jeremiah tradition that is responsible for the portrayal of Jeremiah of the book of Jeremiah. 
Deuteronomic-theological perspective. In terms of this theology the leadership in Judah was regarded a failed leadership. This rigid way of thinking did not go down well with all religious thinkers. We have good examples in the OT Wisdom literature such as Ecclesiasticus and Job who serve as voices protesting against the rigid ideology of retribution. ${ }^{66}$ Kiel says "Qoheleth, like the author of Job, offer life's experiences as a rebuttal to the widely held theological dictum that God treats people according to their actions." life than relating everything to cause-and-effect and we should be cautioned to perpetuate a similar dogma of retribution in societies today.

\section{REFLECTION ON THE PROCESS}

In reflecting on the process of relating an ancient text such as the OT to modern day leadership issues, the following should be mentioned. Reading and analysis of Jer 5:1-9 has shown that Jeremiah had a concern about the society, but that the leaders in particular have failed Yahweh and the people. The process followed in this article was first to demarcate the passage by attending to the structural makers displayed in the text and then to analyse the text in terms of its syntax, rhetoric and content. I have also attempted to analyse the passage with a concern for the literary context in which this passage appears in the book of Jeremiah as well as the historical context presented by the text. The detailed analysis also revealed the possibility that people who at a later stage collected the oracles of Jeremiah, already interpreted 5:1-6 departing from concerns in their own societies, possibly the exilic or postexilic society. As argued before, I regard 5:7-9 as such a later re-reading of material from a different period in time. After highlighting some issues relating to leadership or even the failure of leadership the next step was to critically engage these issues from the perspective of the reader of the Jeremiah text. Some concerns were raised with regard to relating aspects emanating from different worldviews with each other and I suggested ways of how we can still constructively engage ancient texts. I have also critiqued some of the ideologies of concern from my perspective as a critical reader situated in a modern day society. Finally I concluded by claiming that engaging texts with a religious perspective is still a meaningful endeavour and a necessary exercise.

\section{BIBLIOGRAPHY}

Adeogun, Ebenezer O. O. "The Kingdom of God and Old Testament Theocracy." Ogbomoso Journal of Theology 12 (2007): 69-70

66 Marc A. Jolley, "Retribution," EDB: 1122 say Job, Jeremiah and Psalms of lament question the idea of retribution and seek explanations for suffering. This way the idea of retribution and the theodicy question is closely linked.

67 Micah D. Kiel, "Ecclesiastes," in Fortress Commentary on the Bible: The Old Testament and Apocrypha (ed. Gale A. Yee, Hugh R. Page, Jr., and Matthew J. M. Coomber; Minneapolis: Fortress, 2014), 628. 
Albertz, Rainer. "Jer 2-6 und die Frühzeitverkündigung Jeremias." Zeitschrift für die alttestamentliche Wissenschaft 94 (1982): 20-47.

Allen, Leslie C. Jeremiah. Louisville: Westminster John Knox, 2008.

Batstone, David. "Preserving Integrity, Profitability, and Soul." Pages 463-485 in Business Leadership: A Jossey-Bass Reader. Edited by Joan V. Gallos. San Francisco: Jossey-Bass, 2008.

Birch, Bruce, C., Walter Brueggemann, Terence, E. Fretheim and David, L. Petersen. A Theological Introduction to the Old Testament. Nashville: Abingdon Press, 1999.

Blenkinsopp, Joseph. Sage, Priest, Prophet: Religious and Intellectual Leadership in Ancient Israel. Louisville, Ky.: Westminster John Knox, 1995.

Bolman, Lee G. and Terrence E. Deal. "The Leader as Politician: Navigating the Political Terrain." Pages 336-348 in Business Leadership: A Jossey-Bass Reader. Edited by Joan V. Gallos. San Francisco: Jossey-Bass, 2008.

Brueggemann, Walter. The Book that Breathes New Life. Minneapolis: Fortress, 2005. . Like Fire in the Bones: Listening for the Prophetic Word in Jeremiah. Minneapolis: Fortress, 2006.

Carroll, Robert P. Jeremiah. London: SCM, 1986.

Chapman, Stephen B. "Reading the Bible as Witness: Divine Retribution in the Old Testament." Perspectives in Religious Studies 31/2 (2004): 171-190.

Clines, David J. A. Interested Parties: The Ideology of Writers and Readers of the Hebrew Bible. Sheffield: Sheffield Phoenix Press, 2009.

Davies, Eryl W. Biblical Criticism: A Guide to the Perplexed. London: Bloomsbury, 2013.

Diamond, A. R. Pete. "Jeremiah." Pages 543-559 in Eerdmans Commentary on the Bible. Edited by James D. Dunn and John W. Rogerson. Grand Rapids: Eerdmans, 2003.

Delbecq, Andre L. "Nourishing the Soul of the Leader: Inner Growth Matters." Pages 287-288 in Business Leadership: A Jossey-Bass Reader. Edited by Joan V. Gallos. San Francisco: Jossey-Bass, 2008.

De Waard, Jan. A Handbook on Jeremiah. Winona Lake: Eisenbrauns, 2003.

Domeris, William R. "Jeremiah and the Poor." Pages 52-54 in Uprooting and Planting: Essays on Jeremiah for Leslie Allen. Edited by John Goldingay. New York: T\&T Clark, 2007.

DuBrin, Andrew J. Principles of Leadership. 7th edition. Australia: South-Western, Cengage Learning, 2013.

Duvall, J. Scott and Hays J. Daniel. Grasping God's Word: A Hands-On Approach to Reading, Interpreting, and Applying the Bible. Grand Rapids: Zondervan, 2005.

Forrester, Duncan B. "Social Justice and Welfare." Pages 195-208 in The Cambridge Companion to Christian Ethics. Edited by Robin Hill. Cambridge: Cambridge University Press, 2001.

Fretheim, Terence E. Jeremiah. Macon, Ga.: Smith \& Helwys, 2002.

Holladay, William L. Chapters 1-25. Volume 1 of Jeremiah: A Commentary on the Book of the Prophet Jeremiah. Philadelphia: Fortress, 1986.

Houston, Walter J. Contending for Justice: Ideologies and Theologies of Social Justice in the Old Testament. London: T\&T Clark, 2006.

Jolley, Marc A. "Retribution." Page 1122 in Eerdmans Dictionary of the Bible. Edited by David N. Freedman. Grand Rapids: Eerdmans, 2000. 
892 Wessels, “Calling Leaders to Account,” OTE 28/3 (2015): 874-893

Jones, Gareth. "The Authority of Scripture and Christian Ethics." Pages 16-28 in The Cambridge Companion to Christian Ethics. Edited by Robin Hill. Cambridge: Cambridge University Press, 2001.

Kiel, Micah D. "Ecclesiastes." Pages 627-641in Fortress Commentary on the Bible: The Old Testament and Apocrypha. Edited by Gale A.Yee, Hugh R. Page, Jr., and Matthew J. M. Coomber. Minneapolis: Fortress, 2014.

LeMon, Joel M. and Kent H. Richards, eds. Method Matters: Essays on the Interpretation of the Hebrew Bible in Honor of David L. Petersen. Atlanta: Society of Biblical Literature, 2009.

Leuchter, Mark. "Cult of Personality: The Eclipse of Pre-Exilic Judahite Cult Structures in the Book of Jeremiah." Pages 95-115 in Constructs of Prophecy in the Former \& Latter Prophets \& Other Texts. Edited by Lester L. Grabbe and Martti Nissinen. Atlanta: Society of Biblical Literature, 2011.

Lohfink, Norbert. "Die Gattung der 'historischen Kurzgeschichte' in den letzen Jahren von Juda und in der Zeit des babylonischen Exils." Zeitschrift für die alttestamentliche Wissenschaft 90 (1978): 319-347.

Lundbom, Jack R. Jeremiah Closer Up: The Prophet and the Book. Sheffield: Sheffield Phoenix Press, 2010.

Maier, Christl M. Jeremia als Lehrer der Tora. Göttingen: Vandenhoeck \& Ruprecht, 2002.

McKane, Wiliam. A Critical and Exegetical Commentary on Jeremiah. Edinburgh: T \& T Clark, 1986.

Moberly, R. Walter L. Old Testament Theology: Reading the Hebrew Bible as Christian Scripture. Grand Rapids: Baker Academic, 2013.

O'Connor, Kathleen M. "Reclaiming Jeremiah's Violence." Pages 37-49 in Aesthetics of Violence in the Prophets. Edited by Chris Franke and Julia M. O'Brien. New York: T\&T Clark, 2010.

Oosterhoff, Berend J. Jeremia. Commentaar op het Oude Testament. Kampen: Uitgeversmaatschappij J H Kok, 1990.

Overholt, Thomas W. The Treat of Falsehood: A Study in the Theology of the Book of Jeremiah. London: SCM, 1970.

Reimer, David J. "Redeeming Politics in Jeremiah." Pages121-136 in Prophecy in the Book of Jeremiah. Edited by Hans M. Barstad and Reinhard G. Kratz. Berlin: Walter de Gruyter, 2009.

Reumann, John. "Faith." Pages 453-454 in Eerdmans Dictionary of the Bible. Edited by David N. Freedman. Grand Rapids: Eerdmans, 2000.

Rom-Shiloni, Dalit. "'How Can You Say, "I Am Not Defiled ...”?' (Jeremiah 2:2025): Allusions to Priestly Legal Traditions in the Poetry of Jeremiah." Journal of Biblical Literature 133/4 (2014): 757-775.

Rochester, Kathleen M. Prophetic Ministry in Jeremiah and Ezekiel. Leuven: Peeters, 2013.

Rudolph, Wilhelm. Jeremia. 3rd enhaned ed. Tübingen: JCB Mohr, 1968.

Schmidt, Werner H. Das Buch Jeremia, Kapitel 1-20. Göttingen: Vandenhoeck \& Ruprecht, 2008.

Smith, Morton. Palestinian Parties and Politics that Shaped the Old Testament. New York: Columbia University Press, 1971.

Stulman, Louis. Jeremiah. Nashville: Abingdon Press, 2005. 
Wessels, "Calling Leaders to Account," OTE 28/3 (2015): 874-893 893

Tate, W. Randolph. Biblical Interpretation: An Integrated Approach. Grand Rapids: Baker Academic, 2011.

Tiemeyer, Lena-Sofia. "The Priests and the Temple Cult in the Book of Jeremiah." Pages 233-264 in Prophecy in the Book of Jeremiah. Edited by Hans M. Barstad and Reinhard G. Kratz. Berlin: Walter de Gruyter, 2009.

Williams, Rowan. "Making Moral Decisions." Pages 4-6 in The Cambridge Companion to Christian Ethics. Edited by Robin Hill. Cambridge: Cambridge University Press, 2001.

Wessels, Wilhelm J. "Leaders and Times of Crisis: Jeremiah 5:1-6 a Case in Point." Journal for Semitics, forthcoming.

Prof. Willie Wessels, Department of Biblical and Ancient Studies, University of South Africa. P.O. Box 392, Unisa, 0003, South Africa. Email: wessewj@unisa.ac.za. 